Article

\title{
Effects of Chemical and Natural Additives on Cucumber Juice's Quality, Shelf Life, and Safety
}

\author{
Mohamed T. El-Saadony ${ }^{1, *}$, Mohamed F. Elsadek ${ }^{2,3}, * \mathbb{C}$, Alaa S. Mohamed ${ }^{4}$, Ayman E. Taha ${ }^{5}{ }^{(}$, \\ Badreldin M. Ahmed ${ }^{3}$ and Ahmed M. Saad ${ }^{6}$ (D) \\ 1 Department of Agricultural Microbiology, Faculty of Agriculture, Zagazig University, Zagazig 44511, Egypt \\ 2 Department of Community Health Sciences, College of Applied Medical Sciences, King Saud University, \\ Riyadh 11362, Saudi Arabia \\ 3 Department of Nutrition and Food Science, Faculty of Home Economics, Helwan University, \\ Helwan 11795, Egypt; Badreldin222@gmail.com \\ 4 Food Science Department, Faculty of Agriculture, Zagazig University, Zagazig 44511, Egypt; \\ dr_alla88@yahoo.com \\ 5 Department of Animal Husbandry and Animal Wealth Development, Faculty of Veterinary Medicine, \\ Alexandria University, Rasheed, Edfina 22758, Egypt; Ayman.Taha@alexu.edu.eg \\ 6 Biochemistry Department, Faculty of Agriculture, Zagazig University, Zagazig 44511, Egypt; \\ ahmedm4187@gmail.com \\ * Correspondence: m_tlatelsadony@yahoo.com (M.T.E.-S.); mfbadr@ksu.edu.sa (M.F.E.)
}

Received: 20 April 2020; Accepted: 11 May 2020; Published: 15 May 2020

check for updates

\begin{abstract}
Microbial contamination affects beverages' lifetime, quality, and safety. Cucumber crops are seasonally spoiled because of the overproduction. The current study aimed to maximize the importance of natural preservatives and reduce the usage of artificial ones to prolong the cucumber juice's storage life, enhance flavor, and control the microorganisms after protein isolate and organic acids supplementation. The additions included control (no addition), citric, benzoic acid, sodium salts, kidney bean pepsin hydrolysate (KPH), chicken egg protein isolate (CEPI), duck egg protein isolate (DEPI), and quail egg protein isolate (QEPI) as J-Control, J-Citric, J-Benzoic, J-sod. Citrate, J-sod. Benzoate, J-KPH, J-CEPI, J-DEPI, and J-QEPI, respectively. The antioxidant activity of these additives and juices was evaluated by DPPH radical scavenging activity. The antimicrobial activity, including antibacterial and antifungal activities, was evaluated by using disc assay and the radial growth of fungal mycelium, respectively. The phenolic compounds and flavonoids were estimated by a spectrophotometer as Gallic acid equivalent (GAE) and quercetin equivalent (QE), respectively. Moreover, chemical parameters such as $\mathrm{pH}$, total soluble solids (TSS), Titratable acidity (TTA), and Vitamin C were evaluated by AOAC. Finally, the color properties were estimated by a spectrophotometer, using the Hunter method. KPH had higher significant $(p \leq 0.05)$ antioxidant activity (88\%), along with antimicrobial activity. It significantly $(p \leq 0.05)$ reduced the growth of G+ and G- bacteria by $71-97 \%$ and $58-66 \%$ respectively. Furthermore, it significantly $(p \leq 0.05)$ inhibited the tested fungi growth by $70-88 \%$ and the other additives less than that. During the storage of cucumber juice for an interval of zero, two, four, and six months, the phenolic compounds and flavonoids were significantly $(p \leq 0.05)$ decreased. Consequently, the potential activity of the juice was reduced; in addition, $\mathrm{pH}$ and vitamin $\mathrm{C}$ were significantly $(p \leq 0.05)$ decreased during the storage period. Meanwhile, the TSS and Titratable acidity were significantly raised. As for color and sensory properties, J-sod. Benzoate, J-KPH, J-CEPI, and J-DEPI had significantly ( $p \leq 0.05$ ) high scores in color, taste, and flavor against the control. Generally, the usage of natural additives extends the cucumber juice's lifetime and increased the manufacture of high-quality and valuable juice.
\end{abstract}

Keywords: chemical additives; protein isolates; beverages storage; hyperbaric storage 


\section{Introduction}

The high moisture content in fruit and vegetable juices makes them highly susceptible to being spoiled by microorganisms [1] that can survive in acidic juices at normal temperature or refrigeration conditions, even when appropriately packaged. Moreover, physiochemical changes affect the safety and quality. All of these offensive changes may be prevented by supplementation of preservatives that maintain the nutrition value of juice, extend its lifetime, and keep it safe [2]. Recently, the consumer demand for foods with a long lifetime, high quality, and a suitable price has increased. Therefore, food producers and manufacturers are in quest of additives to increase food storage life, while maintaining nutrition value, quality, and safety. Many chemicals, such as nitrates, organic acids, and their salts, butylated hydroxytoluene (BHT) formaldehyde, and butylated hydroxyanisole (BHA) are effectively used as food preservatives, to reduce the microbial load and prolong food lifetime and vitality. Despite their antioxidant and antimicrobial activity [3,4], preservatives' various undesirable effects on human health, including allergy, headache, asthma, hyperactivity, hypersensitivity, cancer, neurological damage, and dermatitis, have been investigated, [5-7]. Carocho et al. [8] confirmed that the extreme consumption of chemical additives is expounded to gastrointestinal, respiratory, dermatological, and neural opposing responses. Hence, consumers are increasingly concerned about the harmful effects of chemical preservatives and the preference for natural additives. Researchers have focused on producing natural preservatives that exhibit antioxidant and microbial activity for use in food processing $[9,10]$. Dauda et al. [11] evaluated the microbial load during watermelon juice storage over three months at cool conditions. They found that pure watermelon juice was highly vulnerable to microbial spoilage because of preservatives' absence, and a large volume of microbial loads was recorded, but when they mixed the juice with serendipity berry extract as a preservative, the load was highly reduced and the storage life extended.

Cucumber (Cucumis sativus L.) is a member of Cucurbitaceae seasonal vegetable crops, which are native to India and cultivated all over the world [12]. During the harvest season, a large amount of cucumber spoils due to overproduction. This problem can be minimized by saving the cucumber as a drink or juice as functional beverages. In Central Asia, people drink cucumber juice on hot days, for recovery. Cucumber juice has health benefits for skin, nails, and hair; it maintained an ideal weight and cure some kidney disease and blood pressure issues. The cucumber is distinguished by its high content of water and satisfies all appetites [13]. In some regions of the developing countries, refrigeration storage is difficult to use due to the high costs of operating and the deficiency of electricity supplies. Alemu and Girma [14] developed a novel technique for food storage called "Hyperbaric storage", which is usually not higher than $100 \mathrm{MPa}$ at ambient or low temperature, for up to months.

Recent studies showed that the storage with low pressure at room temperature can be an effective technique to fruit and vegetable juices' storage, as pressure inhibits the microbial content of fresh juice, besides enhancing sensory characteristics and the quality of the juice. Reports indicated that low-pressure storage prolonged vegetable and fruit juices' shelf life; it also reduced energy costs more than refrigeration storage [15-18]. Lemos et al. [19] preserved watermelon juice with low pressure (50-75 MPa), at room temperature, for two months. The usage of natural antimicrobial and antioxidants, such as herbal extracts and essential oils, improved capacity and safety in the food industry [20,21]. Moreover, peptides and antimicrobial proteins (AMPs) are responsible for the immunity of most organisms. Because of their activity and stability in foods and drinks, they represent natural preservatives [22]. Various protein hydrolysates have been applied as antioxidants and microbes in meat products $[23,24]$. Saad et al. [25] reported that kidney bean protein hydrolysate improved minced meat quality, shelf life, and safety. Wan and Xu [26] confirmed that whey protein isolates improved sensory and physical-chemical properties of a complimentary beverage. Organic acids exhibit antioxidant properties [3], especially dilute solutions, but they do not affect the sensory properties of food in, the sense that they do not affect the sensory properties of the carcasses [27].

This current study aimed to (i) investigate the effect of natural additives (different egg-white protein isolates; chicken, duck, and quail egg protein isolates; and kidney bean protein hydrolysate) 
and chemical additives (citric, benzoic acids, and their sodium salts) on cucumber-juice flavoring and preservation at room temperature, with low pressure, for an interval of zero, two, four, and six months; (ii) estimate the antioxidant and antimicrobial activities of the protein isolates and hydrolysates; (iii) identify the phenolic compounds and flavonoids in protein isolates and hydrolysates; and (iv) evaluate the sensory properties of juice during the preservation period.

\section{Materials and Methods}

\subsection{Materials}

Cucumber (Cucumis sativus) and kidney bean (Phaseolus vulgaris L.) seeds were purchased from the local market. Chicken, duck, and quail eggs were obtained from a private farm (Zagazig City, Egypt). Proteins' isolates were prepared at Biochemistry Department, Faculty of Agriculture, Zagazig University, Egypt. Pepsin enzyme, DPPH, Gallic acid, quercetin, benzoic acid, sodium benzoate, citric acid, sodium citrate, and nutrient agar media (lab-lemco powder) were purchased from Sigma (Ronkonkoma, NY, USA), MacConkey agar (Heywood, UK). The G+ bacteria (Listeria monocytogenes ATCC 15313, Bacillus cereus ATCC 11778, and G- bacteria (E. coli ATCC 25922, and Pseudomonas aeruginosa ATCC 27853) were purified active strains. Fungi strains, Aspergillus niger, Penicillium notatum, and Fusarium solani were obtained from the Cairo MIRCEN, Ain Shams University, Cairo, Egypt.

\subsection{Methods}

\subsubsection{Preparation of Protein Isolates}

Preparing of Pepsin Kidney Bean Protein Hydrolysate (KPH)

White kidney bean seeds were milled. The obtained flour was defatted with hexane (1:3 w/v) and then dried, in the oven. Total protein was isolated from five grams of defatted white kidney bean flour [28]. The lyophilized total protein isolate was dissolved in phosphate buffer $\mathrm{pH}$ two and hydrolyzed by pepsin enzyme (E:S ratio $1: 200, w / w)$, at $37^{\circ} \mathrm{C}$, for three hours. The enzyme was deactivated in warm water at $90^{\circ} \mathrm{C}$ for fifteen minutes. The supernatant was obtained by centrifugation of hydrolysate at $4000 \times g$ for thirty minutes, lyophilized, and then kept.

Preparation of Chicken, Duck, and Quail Egg White Protein Isolate (CEPI, DEPI, and QEPI)

The chicken, quail, and duck egg whites were diluted [29] with some modification, with water $(1: 3 w / v)$, and were stirred for thirty minutes and centrifuged for 20 min undercooling $(15,000 \times g)$. The obtained supernatant was precipitated with $10 \%$ polyethylene glycol (PEG) 4000 and centrifuged under cooling at $15,000 \times g$ for twenty minutes. The residues were dissolved in $50 \mathrm{mM}$ Tris- $\mathrm{HCl}, 200 \mathrm{mM}$ $\mathrm{NaCl}$, and $5 \mathrm{mM} \mathrm{CaCl}_{2}$, pH 7.8 (TBS-Ca). After leaving at $4{ }^{\circ} \mathrm{C}$ overnight, the mixture was centrifuged $\left(4{ }^{\circ} \mathrm{C}, 15,000 \times g, 20 \mathrm{~min}\right)$. The precipitates were washed with TBS-Ca, homogenized with TBS buffer with ten mM EDTA, pH 7.8, and kept for thirty minutes at $4{ }^{\circ} \mathrm{C}$. Then they were centrifuged at $\left(4{ }^{\circ} \mathrm{C}\right.$, $1400 \times \mathrm{g}, 20 \mathrm{~min}$ ), and the supernatant was collected and adjusted to $\mathrm{pH} 5$ with $\mathrm{HCl}$. Following further centrifugation $\left(4^{\circ} \mathrm{C}, 1400 \times g, 20 \mathrm{~min}\right)$, it was dialyzed against $20 \mathrm{mM}$ Tris- $\mathrm{HCl}, 50 \mathrm{mM} \mathrm{NaCl}(\mathrm{pH}$ 8.0). The dialysate fractions were eluted on the $\mathrm{Q}$ Sepharose column by the gradual concentration of $\mathrm{NaCl}$ solution ( 0.1 to 0.6 molar). The chicken, duck, and quail egg protein's isolates were diluted with $\mathrm{NaCl}$ ( 0.35 to $0.45 \mathrm{M})$ and then freeze-dried.

\subsubsection{Processing of Cucumber Juice Supplemented by Preservatives}

The fresh cucumber was washed, cleaned, and processed in a Braun blender (Blender mixer Type 441), resulting in juice. The juice was heated at $83^{\circ} \mathrm{C}$ for $2-3 \mathrm{~min}$, with a few pressures $75 \mathrm{MPa}$ "hyperbaric preservation" [17,19,30,31] in HIRAYAMA HG-SERIES autoclave (Concord, CA 94520, USA), and immediately cooled-down. Table 1 shows the juices constitutes by the Abbe Refractometer. 
The prepared juices were packed into sterilized bottles $(350 \mathrm{~mL})$ and divided into four groups, each of which included nine bottles, one for control and the others for juices supplemented with chemical and natural additives. The bottles were capped and tightly sealed and stored at room temperature for six months. The following analyses were carried out at intervals of preservation $(0,2,4$, and 6 months).

Table 1. The amount of cucumber juice ingredients preserved via chemical and natural preservatives.

\begin{tabular}{cccccccccc}
\hline \multirow{2}{*}{ Constitutes } & \multicolumn{8}{c}{ Juices in Group } \\
\cline { 2 - 9 } & J-Control & J-Citric & J-Benzoic & J-Sod-Citrate & J-Sod-Benzoate & J-KPH & J-CEPI & J-DEPI & J-QEPI \\
\hline Juice $(\mathrm{mL})$ & 200 & 200 & 200 & 200 & 200 & 200 & 200 & 200 & 200 \\
Citric acid (g) & 0.3 & 0.3 & 0.3 & 0.3 & 0.3 & 0.3 & 0.3 & 0.3 & 0.3 \\
Sugar (g) & 10.4 & 10.4 & 10.4 & 10.4 & 10.4 & 10.4 & 10.4 & 10.4 & 10.4 \\
Citric (g) & - & 0.3 & - & - & - & - & - & - & - \\
Benzoic (g) & - & - & 0.3 & - & - & - & - & - & - \\
Sod citrate (g) & - & - & - & 0.3 & - & - & - & - & - \\
Sod-benzoate (g) & - & - & - & - & 0.3 & - & - & - & - \\
KBH (g) & - & - & - & - & - & 0.3 & - & - & - \\
CEPI (g) & - & - & - & - & - & - & 0.3 & - & - \\
DEPI (g) & - & - & - & - & - & - & - & 0.3 & - \\
QEPI (g) & - & - & - & - & - & - & - & - & 0.3 \\
\hline
\end{tabular}

$\mathrm{KPH}$, kidney bean protein hydrolysate; $\mathrm{CEPI}$, chicken egg protein isolate; DEPI, duck egg protein isolate; QEPI, quail egg protein isolate; J-control, control cucumber juice; J-citric, cucumber juice supported with citric acid, J-benzoic, cucumber juice supported with benzoic acid; J.s-citrate, cucumber juice supported with sodium citrate; J.s-benzoate, cucumber juice supported with sod. Benzoate; J-KPH, cucumber juice supported KBH; J-CEPI, cucumber juice supported with CEPI; J-DEPI, cucumber juice supported with DEPI; J-QEPI, cucumber juice supported with QEPI.

\subsubsection{Chemical Analysis}

\section{Estimation of Physiochemical Parameters}

Titratable acidity of juices was calculated as citric acid $(\mathrm{mg} / \mathrm{mL})$ at the storage period of $0-6$ months, at room temperature, according to standard method 942.15. Additionally, juice $\mathrm{pH}$ was assessed for the same samples by $\mathrm{pH}$ meter. Total soluble solids (TSS \%) was determined by using an Abbe Refractometer (WZS portable refractometer, China). A few drops of the juice were mounted on the tip of the refractometer, and readings were taken [32]. Vitamin C was determined according to Ranganna [33]. A total carbohydrate was estimated according to the Chaplin [34] method. Then, $200 \mu \mathrm{L}$ of hydrolysate sample and glucose standard $(0,20-100 \mu \mathrm{g} / \mathrm{mL})$ was added to $200 \mu \mathrm{L}$ of phenol $(5 \%)$ and $1 \mathrm{~mL}$ of concentrated sulfuric acid. After thirty minutes, the OD was estimated at $\lambda 490 \mathrm{~nm}$. The concentration of total sugars in cucumber juices was calculated by using the linear equation in the glucose standard curve:

$$
\begin{gathered}
y=0.0053 x-0.0193 \\
R^{2}=0.9884
\end{gathered}
$$

where $\mathrm{y}$ is the absorbance, and $\mathrm{x}$ is glucose concentration $(\mu \mathrm{g} / \mathrm{ml})$.

Total Phenolic Compounds (TPC)

Total phenolic compounds (TPC) was assessed in cucumber juices supplemented with chemical preservatives and isolated proteins as GAE $(0,200-1000 \mu \mathrm{g} / \mathrm{mL})$, following the Folin-Ciocalteu method [35], according to the equation of the Gallic acid standard curve:

$$
\begin{gathered}
y=0.001 x+0.1369 \\
R^{2}=0.9987
\end{gathered}
$$

where $\mathrm{y}$ is the absorbance, and $\mathrm{x}$ is Gallic acid concentration $(\mu \mathrm{g} / \mathrm{mL})$. 
Total Flavonoids

Three $\mathrm{mL}$ aliquot of $10 \mathrm{~g} / \mathrm{L} \mathrm{AlCl}_{3}$ ethanoic solution was added to $0.5 \mathrm{~mL}$ of each juice supplemented with chemical preservatives and isolated proteins, the mixtures were then incubated for an hour, at room conditions [36]. The absorbance was estimated at $430 \mathrm{~nm}$. Total flavonoids in samples was measured as QE $(0,20-100 \mu \mathrm{g} / \mathrm{mL})$, using the quercetin acid standard curve equation.

$$
\begin{gathered}
y=0.0023 x-0.0035 \\
R^{2}=0.9989
\end{gathered}
$$

where $y$ is the absorbance, and $\mathrm{x}$ is the quercetin concentration $(\mu \mathrm{g} / \mathrm{mL})$.

\section{DPPH Radical-Scavenging Activity}

DPPH radical-scavenging activity was followed in milk samples, as an indicator of antioxidant activity [37]. An aliquot (100 $\mu \mathrm{L}$ of each sample) was added to $1 \mathrm{~mL}$ of $1 \mathrm{~mL}$ DPPH in ethanol and incubated at room temperature for thirty minutes [38], before measuring the color absorbance at $517 \mathrm{~nm}$ against a control. The percentage of antioxidant activity of free radical DPPH was calculated as follows:

$$
\text { Radical scavenging activity }(\%)=\frac{(\text { A control }- \text { A sample })}{\text { Acontrol }} \times 100
$$

where $A_{\text {control }}$ is the control absorbance, and $A_{\text {sample }}$ is sample absorbance, i.e., DPPH reaction absorbance.

\subsubsection{Color Measurements}

The color of cucumber juices was measured by using a spectrophotometer (Hunter Lab, Color Flex EZ's $45^{\circ} / 0^{\circ}$, Reston, VA, USA). CIELAB system: L* (lightness-darkness), a* (redness-greenness), $\mathrm{b}^{*}$ (yellowness-blueness), H (Hue angle), $\mathrm{C}^{*}$ (Chroma), WI (whiteness index), and differences values were measured. The instrument was calibrated by using a standard white title: $\mathrm{X}=72.26, \mathrm{Y}=81.94$, $\mathrm{Z}=88.141, \mathrm{~L}^{*}=92.46, \mathrm{a}^{*}=-0.86$, and $\mathrm{b}^{*}=-0.16[39]$.

$$
\begin{gathered}
\text { Hue angle }(\mathrm{H})=\tan ^{-1}\left(\frac{\mathrm{b} *}{\mathrm{a} *}\right) \\
\text { Chroma }(\mathrm{C} *)=\left(\mathrm{a} *^{2}+\mathrm{b} *^{2}\right)^{\frac{1}{2}} \\
\left.\mathrm{WI}_{\mathrm{H}}=\mathrm{L}-3 \mathrm{~b} \text { (Hunter } \mathrm{L}, \mathrm{a}, \mathrm{b} \mathrm{C} / 2\right)=10(\mathrm{Y}-21)^{1 / 2}(\mathrm{Y}-0.847 \mathrm{Z}) \mathrm{Y}^{1 / 2}(\mathrm{C} / 2)
\end{gathered}
$$

\subsubsection{Sensory Evaluation}

Eighty members (faculty staff and students) from the Food Science Department, Faculty of Agriculture, Zagazig University, Egypt, evaluated the sensory properties of cucumber juices, (control+ eight juice with different additives), using a scorecard for each sensory attributes (color, odor, flavor, taste, and overall acceptability), using a 9-point Hedonic scale, whereby the scores ranged from dislike extremely (1) to like extremely (9) [40]. The room was illuminated with white light, and each session continued for two hours. Water was provided to each panelist for mouth-rinsing after testing each product, to avoid the carry-over effect.

\subsubsection{Microbial Analysis}

Antibacterial Activity

Antibacterial activity was estimated [41,42]. Paper discs saturated with $30 \mu \mathrm{L}$ of each additive at different concentrations $(0,50,100$, and $200-1000 \mathrm{mg} / \mathrm{mL})$ were then added to Petri dishes containing nutrient agar infected with pathogenic microorganisms, the G+ bacteria (L. monocytogenes and B. cereus), 
and G- bacteria (E. coli and Ps. aeruginosa) incubated at $37^{\circ} \mathrm{C}$ for $24 \mathrm{~h}$. The developed inhibition zones $(\mathrm{mm})$ were manually measured by using a transparent ruler. The negative control was disc-saturated with distilled water. Minimum inhibitory concentration (MIC) was estimated as the lowest concentration and showed a clear zone on MHA plates.

Turbidity (A600) assay was used to determine the extent of the bacterial growth in nutrient broth media suspensions during $24 \mathrm{~h}$ of incubation. The MIC of each sample was added to a tube containing $100 \mu \mathrm{L}$ of pathogenic bacteria in $10 \mathrm{~mL}$ nutrient broth, incubated at $37^{\circ} \mathrm{C}$ and measured every six hours, before recording the turbidity compared with control.

\section{Microbial Count}

Total viable count and coliform bacterial count in cucumber juices supplemented with chemical preservatives and isolated proteins at $0.2 \%(w / v)$ were performed during preservation periods (0-6 months), at room temperature, by using the pour plate technique [43]. First, $1 \mathrm{~mL}(v / v)$ of the sample was diluted with one-fold of $2 \%$ sterile sodium citrate solution, to prepare a suspension. Then, $1 \mathrm{~mL}$ of the suspension was used for the serial dilution of between $10^{-1}$ and $10^{-5}$. After that, $1 \mathrm{~mL}$ of each dilution was placed in sterile disposable Petri dishes (sterilin) in triplicates. At about 44 to $50{ }^{\circ} \mathrm{C}$, the number of different bacteria was determined by using specified media [44-46]. Colon bacteria were counted on MacConkey agar and brooded at $37^{\circ} \mathrm{C}$ for $24 \mathrm{~h}$. The total viable count (TVC) on Agar media was counted and incubated at $25 \mathrm{~m}$, for a period of $72 \mathrm{~h}$. Microbiological results were converted to logarithms (CFU/g).

\section{Antifungal Activity}

The inhibition action of the chemical and natural additives against three fungal species were obtained from the Department of Agricultural Microbiology, Faculty of Agriculture, Zagazig University, Egypt [47,48]. First, $5 \mathrm{~mL}$ of each additive, at different concentrations (0, 50, 100, 200, 400, 800, and $1000 \mu \mathrm{g} / \mathrm{mL}$ ), was poured into potato dextrose agar (PDA) medium in Petri dishes and then protected at $28{ }^{\circ} \mathrm{C}$ for seven days. After $24 \mathrm{~h}$ of incubation, mycelia disk $(5 \mathrm{~mm})$ was carefully picked from the edge of fungal cultures and placed in the center of each Petri dish containing the additives. The PDA plates without any addition or water were prepared as negative and positive controls, respectively. The fungal mycelium's radial growth was recorded $(\mathrm{cm})$. The minimum fungal concentration was estimated according to [49], by inoculating the contents of all the prepared fungi combined with the additives' concentrations in test tubes, as prepared in case of an MIC test on new PDA tubes. All test tubes were nurtured at $28^{\circ} \mathrm{C}$, for 48 to $72 \mathrm{~h}$.

\subsubsection{Statistical Analysis}

The obtained data means were statistically analyzed by using Microsoft Office Excel (version 2019) and ANOVA variance single factor, at a probability level of $p \leq 0.05$; multiple comparisons were carried out, applying the least significant difference (LSD).

\section{Results and Discussion}

Cucumber juice is considered a valuable and therapeutic beverage. It possesses different medicinal properties, such as antimicrobial, antioxidant, and anticancer properties [50].

\subsection{Physiochemical Changes Analysis}

\subsubsection{DPPH Radical-Scavenging Activity of Additives}

Figure 1 shows the antioxidant activity of chemical additives from citric acid, benzoic acid, sodium citrate, and sodium benzoate, as well as natural ones from KPH to QEPI, pepsin kidney bean peptide, chicken egg protein isolate, duck egg protein isolate, and quail egg protein isolate. All preservatives were added at a concentration of $0.2 \%(w / v)$. KBH significantly $(p \leq 0.05)$ exhibits the 
highest radical-scavenging activity, with $88 \%$ compared to TBHQ 93\%, with a relative increase ranging from $5 \%$ to $9 \%$ from DEPI, QEPI, and sodium benzoate.

The antioxidant activity of organic acid and their salts depends on the carboxyl group giving an electron to free radical and converting to less-reactive (stable) acyl free radical that can be reduced into organic acid again or oxidized to dehydro-organic acid [3]. Sarmadi and Ismail [51] and Afandi et al. [52] investigated the free-radical-scavenging action of protein isolates and hydrolysate with two mechanisms, hydrogen atom transfer (HAT) and single electron transfer (SET). They may act in parallel or with one dominating, according to protein isolate structure, wherein the aromatic amino acids convert radicals to stable molecules by donating electrons, but keeping their own stability. Hydrophobic amino acids improve peptides' solubility in lipids through hydrophobic side chains. Meanwhile, essential and acidic amino acids act as metal ion chelators and proton donners through their $\mathrm{COOH}$ and $\mathrm{NH}_{2}$ side chain.

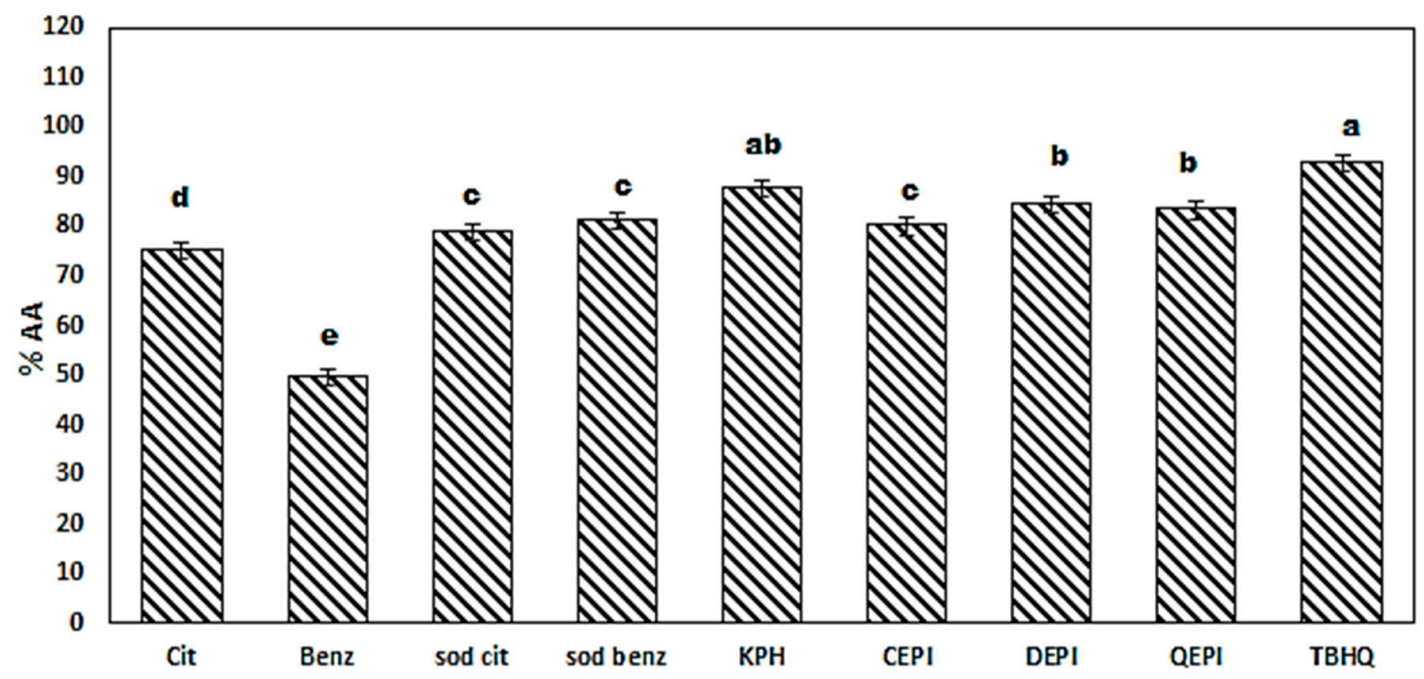

Figure 1. DPPH radical-scavenging activity of cucumber peel after $30 \mathrm{~min}$ compared with TBHQ. Mean with different letters above each column are significantly different $(p \leq 0.05)$.

\subsubsection{Antioxidant Activity of Cucumber Juice}

Figure 2 shows the antioxidant activity changes of cucumber juices during the storage period of zero, two, four, and six months period. The antioxidant activity of cucumber juices significantly $(p \leq 0.05)$ decreased. There was no significant decrement in J-KPH, with the smallest relative decrease about $1.5 \%$; the antioxidant activity relatively reduced from $7 \%$ to $14 \%$ for juices from J-QEPI to J-control. Klimczak et al. [53] reported that the decrease in antioxidant activity might be linked to a reduction in total phenolic content and vitamin C during storage. Protein-phenolic complexes' formation may affect the physical and chemical properties of the protein. Moreover, the phenolics-proteins binding due to blocking some amino acid side chains possibly increased the activity. Furthermore, the protein-phenolic complex may also increase the bioaccessibility and activity of phenolics [54-58].

\subsubsection{Phenolic Compounds and Flavonoids}

Table 2 shows that the significant $(p \leq 0.05)$ relative decrease of total phenolic content ranged from $9 \%$ to $23 \% \mathrm{GAE} \mu \mathrm{g} / \mathrm{mL}$ after six months. Besides, flavonoids were significantly $(p \leq 0.05)$ decreased from 38.515-29.727 to 29.764-22.212 QE $\mu \mathrm{g} / \mathrm{mL}$ after six months, for juices. Vallverdu-Queralt et al. [59] found a decrease in total polyphenol content of tomato juices after three, six, and nine months of storage. Consequently, Kaur et al. [60] showed a significant reduction of phenolic compounds during the six-month storage of cucumber juice supplemented with chemical additives. The protein isolates significantly $(p \leq 0.05)$ maintained the fluids more than the chemically treated sample. The lowest decrement was found in J-KPH, with about $9 \%$ relative decrease. 


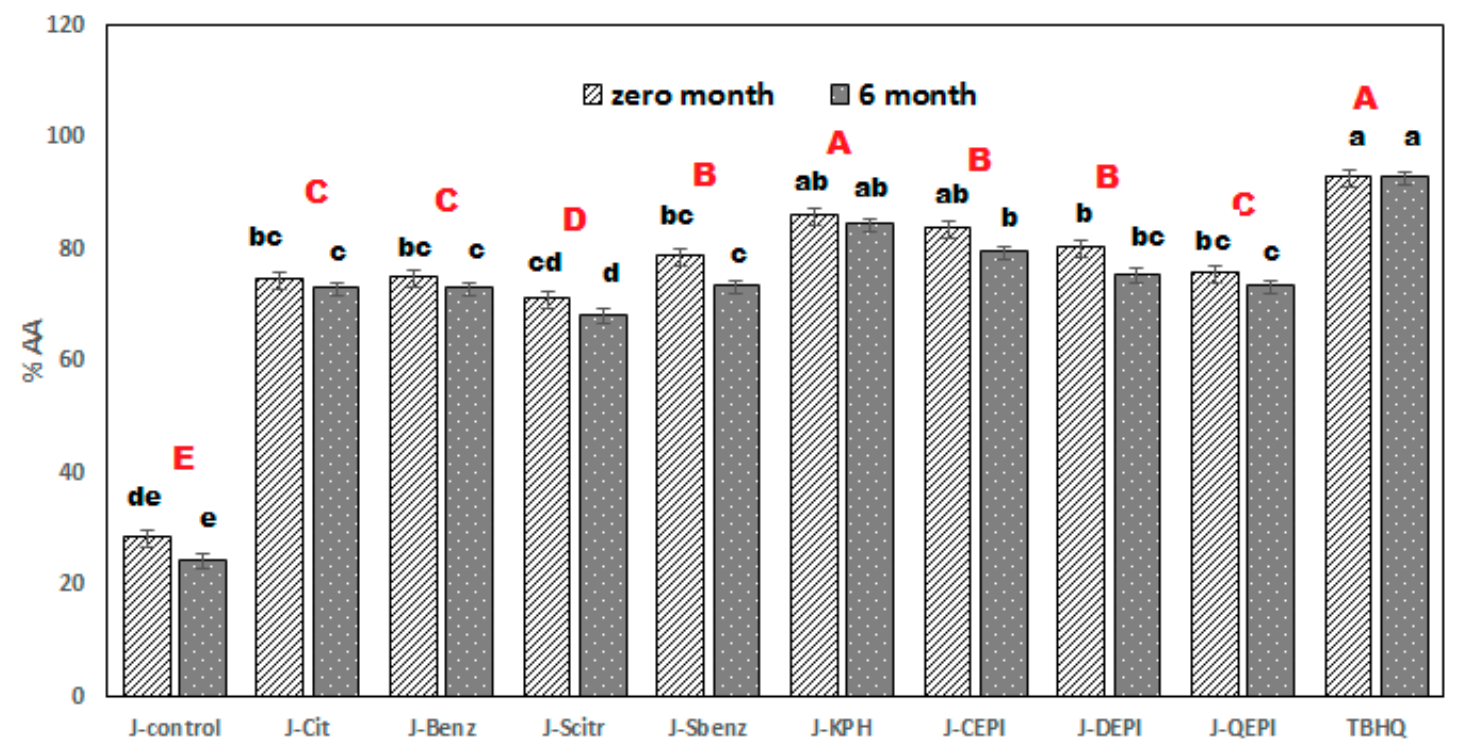

Figure 2. Antioxidant activity changes of cucumber juices during the storage period. Means with different lowercase letters that sit above columns are significantly different during storage, with different red capital letters, and significantly different between samples $(p \leq 0.05)$. J-control, control cucumber juice; J-citric, cucumber juice supported with citric acid, J-benzoic, cucumber juice supported with benzoic acid; J.s-citrate, cucumber juice supported with sodium citrate; J.s-benzoate, cucumber juice supported with sod. Benzoate; J-KPH, cucumber juice supported $\mathrm{KBH}$; J-CEPI, cucumber juice supported with CEPI; J-DEPI, cucumber juice supported with DEPI; J-QEPI, cucumber juice supported with QEPI.

Table 2. Changes in total phenolic compounds and flavonoids during period storage.

\begin{tabular}{ccccc}
\hline & \multicolumn{4}{c}{ TPC } \\
\cline { 2 - 5 } Sample & \multicolumn{4}{c}{ SFC } \\
\cline { 2 - 5 } & $\mathbf{0}$ & $\mathbf{6}$ & $\mathbf{0}$ & $\mathbf{6}$ \\
\cline { 2 - 5 } & $532.74 \pm 0.7 \mathrm{f}$ & $409.10 \pm 1.1 \mathrm{e}$ & $38.515 \pm 1.2 \mathrm{e}$ & $29.764 \pm 0.9 \mathrm{e}$ \\
\hline J-control & $1228.03 \pm 0.5 \mathrm{~b}$ & $1111.10 \pm 0.9 \mathrm{~b}$ & $47.000 \pm 0.9 \mathrm{~d}$ & $44.872 \pm 1.2 \mathrm{c}$ \\
J-Citric & $933.46 \pm 0.6 \mathrm{~d}$ & $739.10 \pm 0.8 \mathrm{c}$ & $45.788 \pm 0.8 \mathrm{~d}$ & $43.714 \pm 1.3 \mathrm{c}$ \\
J-Benzoic & $1284.39 \pm 0.25 \mathrm{~b}$ & $1028.10 \pm 1.3 \mathrm{~b}$ & $34.879 \pm 0.6 \mathrm{e}$ & $33.290 \pm 0.8 \mathrm{~d}$ \\
J-Sod-Benzoate & $1133.81 \pm 0.1 \mathrm{c}$ & $904.10 \pm 1.2 \mathrm{~b}$ & $45.182 \pm 0.7 \mathrm{~d}$ & $43.135 \pm 0.8 \mathrm{c}$ \\
J-Sod-Citrate & $1417.96 \pm 0.9 \mathrm{a}$ & $1268.10 \pm 0.9 \mathrm{a}$ & $120.030 \pm 1.3 \mathrm{a}$ & $99.212 \pm 0.5 \mathrm{a}$ \\
J-KPH & $1166.60 \pm 0.4 \mathrm{c}$ & $931.10 \pm 0.7 \mathrm{~b}$ & $100.636 \pm 1.6 \mathrm{~b}$ & $96.125 \pm 0.25 \mathrm{a}$ \\
J-CEPI & $1088.89 \pm 0.22 \mathrm{~d}$ & $867.10 \pm 1.5 \mathrm{c}$ & $54.879 \pm 1.9 \mathrm{c}$ & $52.401 \pm 1.2 \mathrm{~b}$ \\
J-DEPI & $770.74 \pm 1 \mathrm{e}$ & $605.10 \pm 1.6 \mathrm{~d}$ & $29.727 \pm 2 \mathrm{f}$ & $22.212 \pm 2.3 \mathrm{e}$ \\
J-QEPI &
\end{tabular}

Mean \pm SD. Cucumber-juice means in the same column with different letters are significantly different $(p \leq 0.05)$ J-control, control cucumber juice; J-citric, cucumber juice supported with citric acid, J-benzoic, cucumber juice supported with benzoic acid; J.s-citrate, cucumber juice supported with sodium citrate; J.s-benzoate, cucumber juice supported with sod. Benzoate; J-KPH, cucumber juice supported $\mathrm{KBH}$; J-CEPI, cucumber juice supported with CEPI; J-DEPI, cucumber juice supported with DEPI; J-QEPI, cucumber juice supported with QEPI.

\subsubsection{Chemical Parameters}

Table 3 shows that total sugars significantly $(p \leq 0.05$ ) decreased from the range of $278.81-170.70 \mathrm{mg}$ for J-control-J-QEPI, on the day of preparation, to the range of $95.79-52.40 \mathrm{mg}$ after six months, a relative decrease of $65-70 \%$. Juice acidity was increased because of total sugar in juice analyzed into simple sugar by the fermentative effect of acid-producing bacteria in agreement with Sivakumar [61]. Although TSS not significantly increase because of increments of simple sugars (Figure 3D), Kausar et al. [62] observed that TSS increased (15.49-16.09\%) during the storage of cucumber-melon drink [50] and cucumber-mint drink. Similar results were noticed in watermelon juice blended with ginger obtained 
by [63]. Kinh et al. [64] reported an increase in soluble content of apple pulp during storage when preserved with chemical preservatives. Figure 3A shows significant $(p \leq 0.05)$ decreasing of $\mathrm{pH}$ value, from 4.4 to 3.6 , in all samples after six months, with a relative decrease of about $25-30 \%$. Besides that, the results indicated that $\mathrm{pH}$ changes occur less in natural additives than in chemical and control. The $\mathrm{pH}$ decreased because of increasing in acidity. Aderinola et al. [65] observed a decrease in $\mathrm{pH}$ values and an increase in TTA during the storage of carrot-cucumber juice; these changes might occur due to the fermentation of sugar present in the juice. The acidity in juices J-control to J-Sod-Benz significantly $(p \leq 0.05)$ increased more than fluids supplemented with protein isolates (Figure $3 \mathrm{C}$ ), and the changes were significant at least in J-KPH, J-CEPI, and J-DEPI. As per results, natural additives $>$ chemical additives have a significant $(p \leq 0.05)$ effect on Vitamin $C$ content of cucumber juice. On the storage debut, the Vitamin $C$ content in cucumber juices ranged from 5 to $5.3 \mathrm{mg} / 100 \mathrm{~g}$, respectively. The values significantly $(p \leq 0.05)$ faded, as heat treatment destroys, at the end of the storage period to 2.5-2.3 (Figure 3B). Francis et al. [66] detected the decrement in vitamin C of watermelon juices blended with sodium benzoate and lime; this degradation might be due to the high sensitivity of light, oxygen, heat, and enzymatic or non-enzymatic oxidation.

Table 3. Changes of total sugars during storage for zero and six months, at room temperature.

\begin{tabular}{ccccc}
\hline \multirow{2}{*}{ Sample } & \multicolumn{4}{c}{ Storage Period (Month) } \\
\cline { 2 - 5 } & $\mathbf{0}$ & $\mathbf{2}$ & $\mathbf{4}$ & $\mathbf{6}$ \\
\hline J-control & $278.81 \pm 0.5 \mathrm{~b}$ & $104.09 \pm 0.3 \mathrm{c}$ & $89.19 \pm 0.2 \mathrm{~b}$ & $95.79 \pm 0.1 \mathrm{~b}$ \\
J-Citric & $259.38 \pm 0.2 \mathrm{~b}$ & $91.64 \pm 0.8 \mathrm{~d}$ & $67.49 \pm 0.4 \mathrm{c}$ & $85.23 \pm 0.3 \mathrm{c}$ \\
J-Benzoic & $207.68 \pm 0.8 \mathrm{c}$ & $76.55 \pm 0.9 \mathrm{e}$ & $54.28 \pm 0.6 \mathrm{~d}$ & $67.87 \pm 0.2 \mathrm{~d}$ \\
J-Sod-Benzoate & $106.36 \pm 0.9 \mathrm{f}$ & $49.19 \pm 0.7 \mathrm{f}$ & $30.13 \pm 0.2 \mathrm{e}$ & $35.79 \pm 0.7 \mathrm{f}$ \\
J-Sod-Citrate & $298.81 \pm 0.7 \mathrm{a}$ & $192.77 \pm 1.2 \mathrm{a}$ & $143.53 \pm 0.8 \mathrm{a}$ & $133.53 \pm 0.9 \mathrm{a}$ \\
J-KPH & $121.45 \pm 0.1 \mathrm{e}$ & $95.79 \pm 1.3 \mathrm{~d}$ & $66.50 \pm 0.6 \mathrm{c}$ & $50.20 \pm 1 \mathrm{~d}$ \\
J-CEPI & $115.04 \pm 0.13 \mathrm{f}$ & $91.08 \pm 0.5 \mathrm{~d}$ & $38.43 \pm 0.7 \mathrm{e}$ & $33.53 \pm 1.2 \mathrm{f}$ \\
J-DEPI & $129.38 \pm 0.2 \mathrm{e}$ & $107.87 \pm 0.4 \mathrm{c}$ & $55.09 \pm 0.5 \mathrm{~d}$ & $45.25 \pm 1.3 \mathrm{e}$ \\
J-QEPI & $170.70 \pm 0.3 \mathrm{~d}$ & $155.04 \pm 0.1 \mathrm{~b}$ & $58.62 \pm 0.5 \mathrm{~d}$ & $52.40 \pm 0.9 \mathrm{~d}$ \\
\hline
\end{tabular}

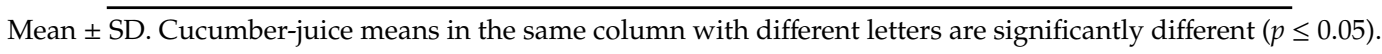
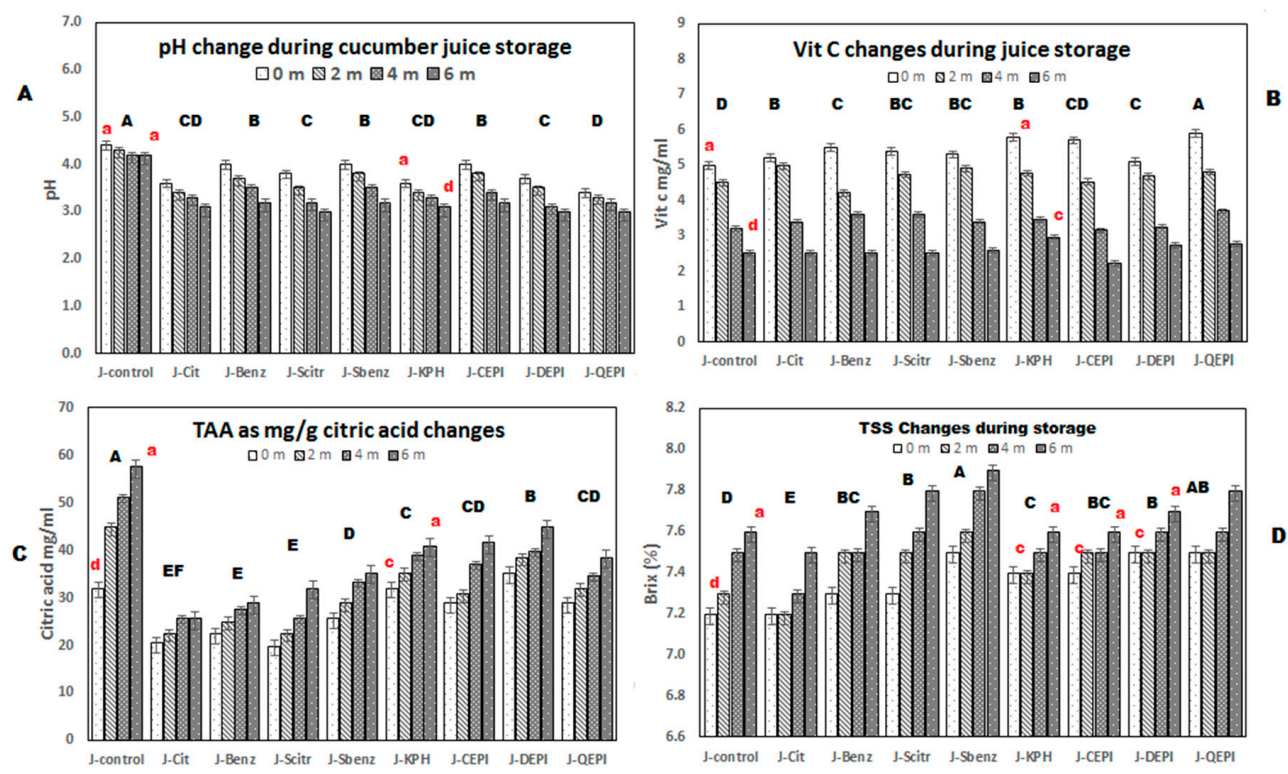

Figure 3. Chemical parameters' changes during cucumber juices storage for zero to six months, at room temperature. Mean with different red lowercase letters that above columns are significantly different during storage, with different capital letters, significantly different between samples $(p \leq 0.05)$. (A) $\mathrm{pH}$ change during cucumber juice storage; (B) Vit $C$ change during juice storage; (C) TAA as mg/g citric acid changes; (D) TSS changes during storage. 


\subsection{Color Measurements and Sensory Evaluation}

Table 4 showed the juices color parameters, where the $\mathrm{L}^{*}$ non-significant decrease from 29.24 for control to 28.7 at the end of storage, with low relative decrease $3 \%$, nearly no change in a, and slightly increase in $\mathrm{b}$ from 11.27 to 11.29 . The significant $(p \leq 0.05)$ best color, according to $\mathrm{L}^{*}$ results, was juice five, supplemented with sodium benzoate. Besides, J-KPH increased in $\mathrm{L}^{*}$ from 28.05 to 29.03 with a relative increase of $4 \%$, decreased in $\mathrm{a}^{*}$ from -3.2 to -3.4 , and showed no change in $\mathrm{b}^{*}$. J-sod-citrate was significantly less white, and other color parameters, $L^{*} 22.8, a^{*} 0.44$, and $b^{*} 11$, increased after six months to $23,0.76$, and 12 . Tomato juice with Na benzoate seems to be more stable than the other preservatives during six months of storage and was less off-color and developed less turbidity $[60,67]$.

Table 4. Changes in color parameters during juices' storage.

\begin{tabular}{|c|c|c|c|c|c|c|c|c|}
\hline \multirow{2}{*}{ Juices } & \multicolumn{8}{|c|}{0 Months } \\
\hline & $\mathbf{L}$ & $\mathbf{a}$ & $\mathbf{b}$ & $C^{*}$ & $\mathbf{h}$ & WI & Differences & $\mathbf{b} / \mathbf{a}$ \\
\hline J-control & $29.24 \mathrm{~b}$ & $-3.3 c$ & $11.27 \mathrm{~b}$ & 11.74 & -73.7 & 28.27 & 0 & -3.42 \\
\hline J-Citric & $27.77 \mathrm{~d}$ & $-2.91 b$ & $10.81 \mathrm{c}$ & 11.19 & -74.91 & 26.91 & 1.59 & -3.71 \\
\hline J-Benzoic & $28.61 \mathrm{c}$ & $-2.81 b$ & $11.63 \mathrm{~b}$ & 11.96 & -76.42 & 27.61 & 0.88 & -4.14 \\
\hline J-Sod-Benzoate & $22.8 \mathrm{e}$ & $0.44 \mathrm{a}$ & $11 \mathrm{c}$ & 11.01 & 87.71 & 22.02 & 7.45 & 25 \\
\hline J-Sod-Citrate & $32.44 \mathrm{a}$ & $-3.69 c$ & $11.64 \mathrm{~b}$ & 12.21 & -72.39 & 31.35 & 3.24 & -3.15 \\
\hline $\mathrm{J}-\mathrm{KPH}$ & $28.05 c$ & $-3.23 c$ & $10.46 \mathrm{c}$ & 10.95 & -72.85 & 27.22 & 1.44 & -3.24 \\
\hline J-CEPI & $28.45 c$ & $-3.33 c$ & $13.32 \mathrm{a}$ & 13.73 & -75.96 & 27.14 & 2.2 & -4 \\
\hline J-DEPI & $27.63 \mathrm{~d}$ & $-2.67 b$ & $12.96 \mathrm{a}$ & 13.23 & -78.35 & 26.43 & 2.42 & -4.85 \\
\hline $\mathrm{J}$-QEPI & $29.08 \mathrm{~b}$ & $-3.92 c$ & $13.56 \mathrm{a}$ & 14.12 & -73.88 & 27.69 & 8.06 & -3.46 \\
\hline \multirow{2}{*}{ Juices } & \multicolumn{8}{|c|}{6 Months } \\
\hline & L & a & $\mathbf{b}$ & $C^{*}$ & h & WI & differences & $\mathbf{b} / \mathbf{a}$ \\
\hline J-control & $28.7 \mathrm{~b}$ & $-3.33 c$ & $11.29 \mathrm{c}$ & 11.77 & -73.56 & 27.73 & 0 & -3.39 \\
\hline J-Citric & $27.9 \mathrm{c}$ & $-2.81 b$ & $10.9 c$ & 11.26 & -75.55 & 27.03 & 1.03 & -3.88 \\
\hline J-Benzoic & $28.9 \mathrm{~b}$ & $-2.79 b$ & 11.43 & 11.77 & -76.29 & 27.93 & 0.59 & -4.1 \\
\hline J-Sod-Benzoate & $23 \mathrm{~d}$ & $0.76 \mathrm{a}$ & $12 \mathrm{~b}$ & 11.03 & 86.05 & 22.21 & 7.02 & 14.47 \\
\hline J-Sod-Citrate & $33 \mathrm{a}$ & -3.71 & $11.64 \mathrm{c}$ & 12.22 & -72.33 & 31.9 & 4.33 & -3.14 \\
\hline $\mathrm{J}-\mathrm{KPH}$ & $29.03 \mathrm{~b}$ & $-3.4 c$ & $10.46 \mathrm{~d}$ & 11 & -72.01 & 28.18 & 0.9 & -3.08 \\
\hline J-CEPI & $28.6 \mathrm{~b}$ & $-3.4 c$ & $13.65 \mathrm{a}$ & 14.07 & -76 & 27.23 & 2.36 & -4.01 \\
\hline J-DEPI & $27.9 \mathrm{c}$ & $-2.5 b$ & $12.99 \mathrm{~b}$ & 13.23 & -79.11 & 26.7 & 2.05 & -5.2 \\
\hline J-QEPI & $30 \mathrm{a}$ & $-8 d$ & $13.71 \mathrm{a}$ & 15.87 & -59.68 & 28.22 & 11.54 & -1.71 \\
\hline
\end{tabular}

Means in the same column with different letters are significantly different $(p \leq 0.05) . L^{*}$ (lightness-darkness), $a *$ (redness-greenness), $b$ * (yellowness-blueness), H (Hue angle), C* (Chroma), WI (whiteness index.

Packing material, storage time, temperature, pressure, and microbial contamination intensely alter juice flavor. Due to all of these factors, furfural increased during storage, as an indicator of acid hydrolysis of alcohols and terpenes. The sensory observations during the storage period are shown in Table 5 , and it is seen that there is a slight significant $(p \leq 0.05)$ variation in color among the nine samples during the storage period. The color was found to be yellow/dark yellow/reddish on the day of preparation. The color faded and flavor declined gradually with the increase of storage period at room conditions. Juices five, six, seven, and eight were the best in color stability and overall acceptability, and juice nine was the worst-rated [65]. 
Table 5. Sensory properties of cucumber juices during the storage period.

\begin{tabular}{ccccc}
\hline \multirow{2}{*}{ Juices } & \multicolumn{3}{c}{ 0 Months } \\
\cline { 2 - 5 } & Color & Taste & Flavor & Overall Acceptability \\
\hline J-control & $8 \mathrm{c}$ & $8.5 \mathrm{a}$ & $8.3 \mathrm{~b}$ & $8.27 \mathrm{~b}$ \\
J-Citric & $8.5 \mathrm{~b}$ & $8.7 \mathrm{a}$ & $8.5 \mathrm{a}$ & $8.57 \mathrm{a}$ \\
J-Benzoic & $8.4 \mathrm{~b}$ & $8.2 \mathrm{~b}$ & $8.9 \mathrm{a}$ & $8.50 \mathrm{a}$ \\
J-Sod-Benzoate & $7.5 \mathrm{c}$ & $8.9 \mathrm{a}$ & $8.8 \mathrm{a}$ & $8.70 \mathrm{a}$ \\
J-Sod-Citrate & $8.3 \mathrm{~b}$ & $8.6 \mathrm{a}$ & $8.2 \mathrm{~b}$ & $8.37 \mathrm{~b}$ \\
J-KPH & $9 \mathrm{a}$ & $8.8 \mathrm{a}$ & $8.6 \mathrm{a}$ & $8.80 \mathrm{a}$ \\
J-CEPI & $8.1 \mathrm{c}$ & $7 \mathrm{c}$ & $7.5 \mathrm{c}$ & $7.53 \mathrm{c}$ \\
J-DEPI & $7.9 \mathrm{c}$ & $6.7 \mathrm{c}$ & $7.3 \mathrm{c}$ & $7.30 \mathrm{c}$ \\
J-QEPI & $7.9 \mathrm{c}$ & $7.1 \mathrm{c}$ & $7.1 \mathrm{c}$ & $7.37 \mathrm{c}$ \\
\hline & & & $6 \mathrm{Months}$ & \\
\hline J-control & $6.75 \mathrm{c}$ & $7.15 \mathrm{~b}$ & $7 \mathrm{a}$ & $6.97 \mathrm{~b}$ \\
J-Citric & $7.25 \mathrm{bc}$ & $7.35 \mathrm{~b}$ & $7.2 \mathrm{a}$ & $7.27 \mathrm{a}$ \\
J-Benzoic & $7.15 \mathrm{bc}$ & 6.85 & $7.6 \mathrm{a}$ & $7.20 \mathrm{a}$ \\
J-Sod-Benzoate & 6.8 & $7.55 \mathrm{a}$ & $7.5 \mathrm{a}$ & $7.60 \mathrm{a}$ \\
J-Sod-Citrate & $8 \mathrm{a}$ & $7.25 \mathrm{~b}$ & $6.9 \mathrm{~b}$ & $7.07 \mathrm{~b}$ \\
J-KPH & $7.75 \mathrm{~b}$ & $7.45 \mathrm{a}$ & $7.3 \mathrm{a}$ & $7.50 \mathrm{a}$ \\
J-CEPI & $6.85 \mathrm{c}$ & $5.65 \mathrm{~d}$ & $6.2 \mathrm{~b}$ & $6.23 \mathrm{~b}$ \\
J-DEPI & $6.65 \mathrm{c}$ & $5.35 \mathrm{~d}$ & $6 \mathrm{~b}$ & $6.00 \mathrm{~b}$ \\
J-QEPI & $6.65 \mathrm{c}$ & $5.75 \mathrm{~d}$ & $5.8 \mathrm{c}$ & $6.07 \mathrm{~b}$ \\
\hline
\end{tabular}

Means in the same column with different letters are significantly different $(p \leq 0.05)$.

\subsection{Microbial Analysis}

\subsubsection{Antibacterial Activity of Additives}

Table 6 shows the inhibition zones diameter (IZD) of chemical and natural preservatives at MIC levels. The MIC of G+ bacteria was $50 \mu \mathrm{g} / \mathrm{mL}$ for additives; citric, sod-citrate, sod-benzoate, $\mathrm{KPH}$, and DEPI, and 100 for the rest; however, the MIC for G- bacteria was 50 for KPH and DEPI; 100 for sod-benzoate, CEPI, and QEPI; 200 for citric and sod-citrate; and 400 for Benzoic, as shown in Table 6. The Gram-positive strain showed higher vulnerability values than the Gram-negative one. B. cereus and L. monocytogenes recorded IZD ranging from 20 to $33 \mathrm{~mm}$ and 21 to $30 \mathrm{~mm}$ for sodium benzoate and KBP, respectively. E. coli and Ps. aeruginosa have the lowest IZD for tested additives (11-18 mm) for citric acid, sodium citrate, and benzoic acid. KBP had a significantly higher $(p \leq 0.05)$ IZD, and QPI had the lowest. The lower zones of inhibition observed in the G- organisms compared to the G+ organisms due to the peptidoglycan-containing periplasmic space and the outer membrane lipopolysaccharide layer of G- bacteria acts as a barrier, preventing the penetration of numerous environmental substances [68], including antimicrobial substances, into the organism. The periplasmic space is also known to contain enzymes capable of breaking down foreign molecules attempting to gain entry into the microorganism $[69,70]$.

\subsubsection{Antifungal Activity}

Table 6 showed the inhibition of fungal radial growth $(\mathrm{Cm})$ of chemical and natural preservatives, where the lowest MFC ranged from 800 to $1000 \mu \mathrm{g} / \mathrm{mL}$ for all fungal strains. KPH had the significant highest $(p \leq 0.05)$ values in fungal growth inhibition, followed by sodium benzoate, DEPI, and CEPI, as shown in Table 6 . The antifungal action of organic acids and protein isolates is reported according to $[4,69-71]$. 
Table 6. Antimicrobial activity of chemical and natural additives.

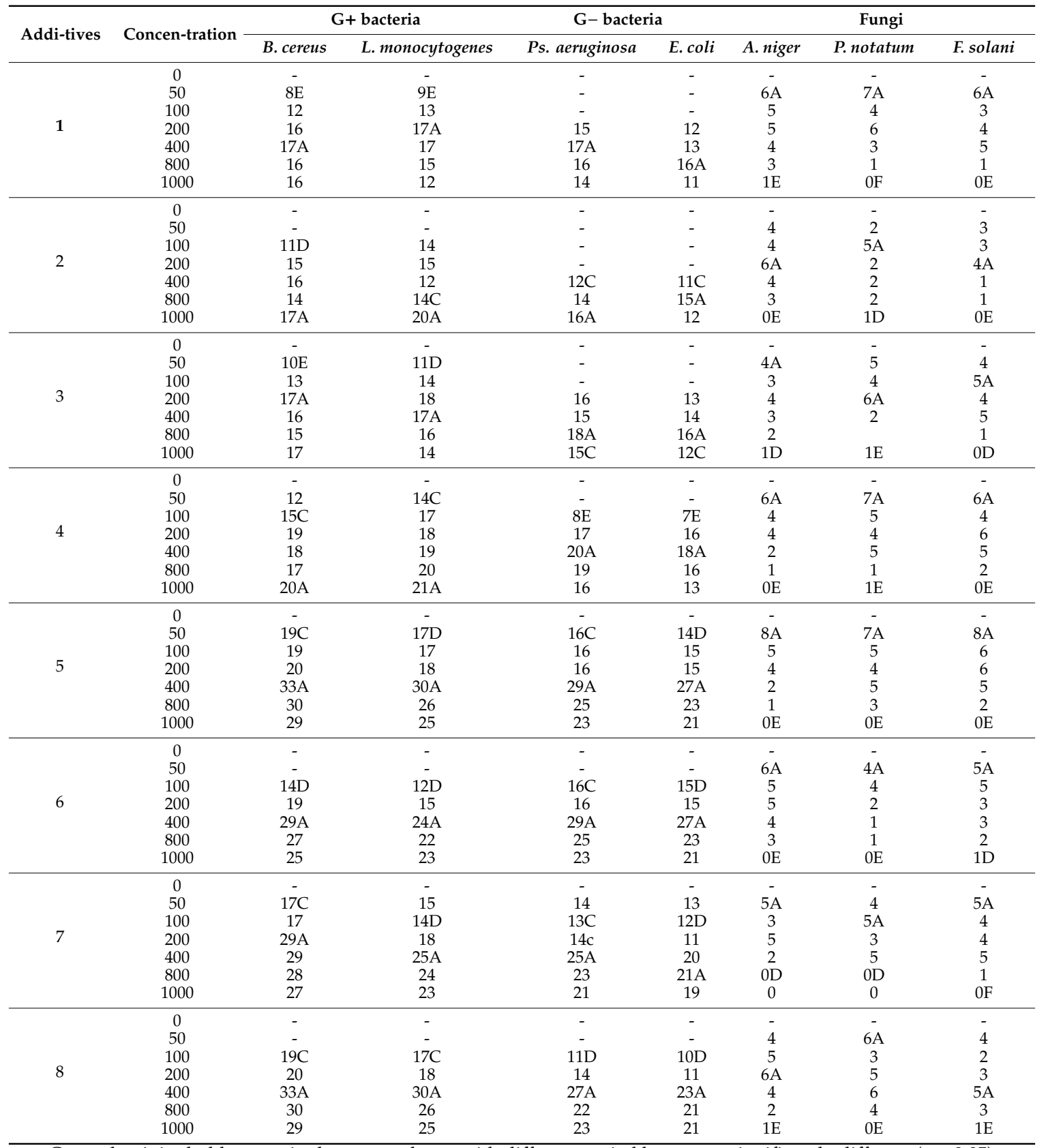

Cucumber juice bold means in the same column with different capital letters are significantly different $(p \leq 0.05)$

\subsubsection{Bacterial Growth Curve}

The growth curves of the tested bacteria reached the highest turbidity after about $16 \mathrm{~h}$ at $37^{\circ} \mathrm{C}$ in E. coli and Ps. aeruginosa, but after $12 \mathrm{~h}$ in B. cereus and L. monocytogenes. KBH had significant $(p \leq 0.05)$ values in reducing the growth of Gram-positive bacteria by $71 \%$ and $79 \%$, as well as Gram-negative bacteria by $58 \%$ and $66 \%$, for B. cereus, L. monocytogenes, E. coli, and Ps. aeruginosa, respectively. Generally, chemical additives reduced the growth of $B$. cereus by $10-45 \%$, L. monocytogenes by $18-58 \%$, E. coli by $10-38 \%$, and Ps. aeruginosa by $20-44 \%$.However, the natural ones reduced the G+ bacteria growth by $55-71 \%$ and $53-79 \%$, as well as by $41-58 \%$ and $49-66 \%$ for G- bacteria, as shown in (Figure 4). The antimicrobial mechanism of organic acid penetrated the microorganisms' cell membrane, decreased cell $\mathrm{pH}$, and controlled the processes of metabolism, especially the synthesis of ATP, RNA, protein, and DNA replication [4]. Most of the positively charged peptides are electrostatically bound 
to negatively charged compounds on the bacterial cell wall, leading to cell wall destruction [71-73]. Furthermore, the peptide hydrophobicity plays an essential role in disturbing the bacterial cell membrane and cell wall. MIC was determined from chemical and natural additives against all experimental bacterial strains.
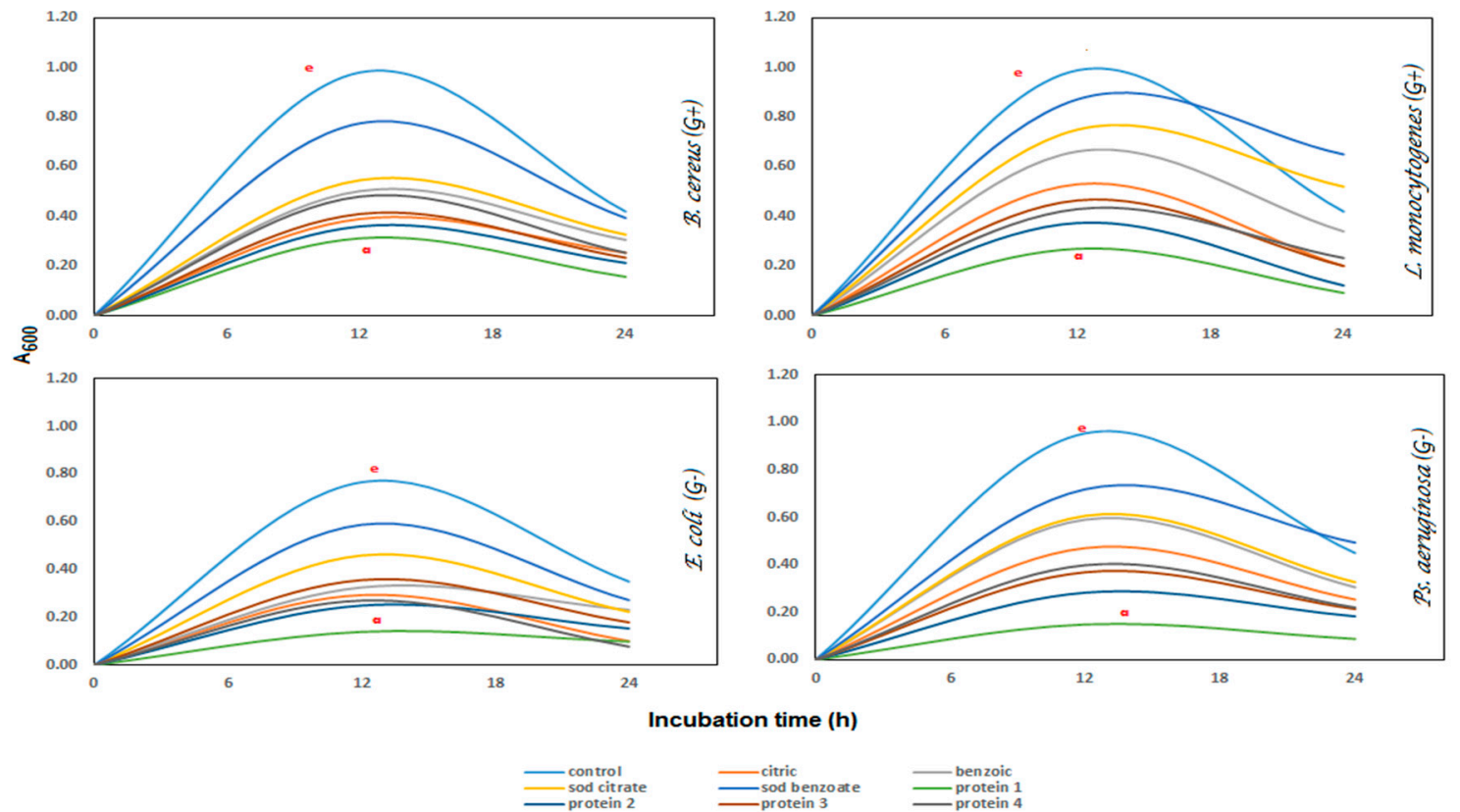

Figure 4. Growth curve of $\mathrm{G}^{+}$and $\mathrm{G}^{-}$bacteria in the presence of additives MIC levels.

\subsubsection{Bacterial Load in Cucumber Juice during Storage}

Table 7 showed that the highest total bacterial count obtained in control during storage ranged from 2.7 to $5(\log \mathrm{CFU} / \mathrm{mL})$ at room temperature, from two to six months. Meanwhile, the bacterial load significantly $(p \leq 0.05)$ decreased in J-citric and J-benzoic decreased from 2.7 to 2.5 , and 2.6 respectively, with about $50 \%$. On the other hand, the bacterial load of J-KPH, J-CEPI, and J-DEPI significantly $(p \leq 0.05)$ decreased with a relative increase of about $60 \%$, because of the antimicrobial potential of protein isolates [71-73]. Similar results were obtained by Habib and Iqbal [30], who observed the least TVC in mixed cucumber-tomato-pumpkin juice, especially in the blend percentage $5 \%-7 \%-9 \%$.

Table 7. TVC and CBC in cucumber juices during the storage period at room temperature.

\begin{tabular}{ccccccccc}
\hline & \multicolumn{7}{c}{ Log CFU/mL } \\
\cline { 2 - 9 } Juices & \multicolumn{2}{c}{ 0 Months } & 2 Months & \multicolumn{2}{c}{ 4 Months } & \multicolumn{2}{c}{ 6 Months } \\
\cline { 2 - 9 } & TVC & CBC & TVC & CBC & TVC & CBC & TVC & CBC \\
\hline J-control & $1.2 \pm 0.1 \mathrm{a}$ & ND & $2.7 \pm 0.2 \mathrm{a}$ & ND & $3.5 \mathrm{a} \pm 0.5$ & $1.3 \mathrm{a} \pm 0.3$ & $5 \mathrm{a} \pm 0.7$ & $1.5 \mathrm{a} \pm 0.2$ \\
J-Citric & $0.9 \pm 0.08 \mathrm{~b}$ & ND & $2.5 \pm 0.19 \mathrm{~b}$ & ND & $2.9 \mathrm{~b} \pm 0.4$ & $0.9 \mathrm{~b} \pm 0.4$ & $4 \mathrm{c} \pm 0.5$ & $1.1 \mathrm{~b} \pm 0.3$ \\
J-Benzoic & $1.2 \pm 0.1 \mathrm{a}$ & ND & $2.6 \pm 0.18 \mathrm{a}$ & ND & $2.95 \mathrm{~b} \pm 0.4$ & $1.1 \mathrm{a} \pm 0.3$ & $4.5 \mathrm{~b} \pm 0.8$ & $1.4 \mathrm{a} \pm 0.5$ \\
J-Sod-Benzoate & $1.1 \pm 0.15 \mathrm{~b}$ & ND & $2.9 \pm 0.3 \mathrm{a}$ & ND & $2.89 \mathrm{~b} \pm 0.4$ & $1.2 \mathrm{a} \pm 0.3$ & $4.7 \mathrm{a} \pm 0.9$ & $1.3 \mathrm{a} \pm 0.4$ \\
J-Sod-Citrate & $0.9 \pm 0.09 \mathrm{~b}$ & ND & $2.5 \pm 0.19 \mathrm{~b}$ & ND & $3.1 \mathrm{c} \pm 0.2$ & $0.8 \mathrm{~b} \pm 0.2$ & $4 \mathrm{c} \pm 0.5$ & $0.9 \mathrm{c} \pm 0.1$ \\
J-KPH & $0.5 \pm 0.03 \mathrm{~d}$ & ND & $2.3 \pm 0.1 \mathrm{c}$ & ND & $2.8 \mathrm{c} \pm 0.3$ & $0.7 \mathrm{c} \pm 0.25$ & $4 \mathrm{c} \pm 0.5$ & $0.9 \mathrm{c} \pm 0.1$ \\
J-CEPI & $0.8 \pm 0.04 \mathrm{c}$ & ND & $2.4 \pm 0.1 \mathrm{~b}$ & ND & $2.89 \pm 0.4$ & $0.8 \mathrm{~b} \pm 0.2$ & $4 \mathrm{c} \pm 0.5$ & $1 \mathrm{~b} \pm 0.15$ \\
J-DEPI & $0.7 \pm 0.05 \mathrm{c}$ & ND & $2.5 \pm 0.19 \mathrm{~b}$ & ND & $3.2 \mathrm{a} \pm 0.6$ & $0.9 \mathrm{~b} \pm 0.4$ & $4.4 \mathrm{c} \pm 0.6$ & $1.3 \mathrm{a} \pm 0.4$ \\
J-QEPI & $0.8 \pm 0.06 \mathrm{c}$ & ND & $2.6 \pm 0.18 \mathrm{a}$ & ND & $3.4 \mathrm{a} \pm 0.6$ & $0.9 \mathrm{~b} \pm 0.4$ & $4.5 \mathrm{~b} \pm 0.6$ & $1.1 \mathrm{~b} \pm 0.3$ \\
\hline
\end{tabular}

ND: not detected; TVC: total viable count; CBC: coliform bacterial counts. Mean \pm SD. Means in the same column with different letters are significantly different $(p \leq 0.05)$. 


\section{Conclusions}

The study was able to establish the $\mathrm{KBH}$, and Sod-Benzoate has a significant effect on the lifetime and sensory properties of the treated juice samples. It could be concluded that cucumber juice blended/enhanced with $\mathrm{KPH}$ and sodium benzoate $(0.2 \%)$ was rated higher when compared to other samples. The addition of KBH to the cucumber juice maintained the storage life of the juice for six months, at room temperature, with 50-75 MPa, thus making it an available meal, ready to serve, and a refreshing drink with a good nutritional, medicinal, and caloric value. The results of this research work confirmed both the vulnerability of pure cucumber juice to a microbial attack due to its high moisture content and the preservative potentials of natural additives, especially $\mathrm{KBH}$, because of their antioxidant and antimicrobial activity. It was observed that $\mathrm{KBH}$ had two significant roles in the juice samples; that of a flavor (natural) and a preservative. We recommended the utilization of natural additives because of their safety, unlike chemical ones. Finally, this preservation method protected the cucumber crop from spoilage and increased the manufacture of high-quality and valuable juice.

Author Contributions: Conceptualization, M.T.E.-S. and A.S.M.; data curation, A.E.T.; funding acquisition, data analysis and collection, M.F.E. and B.M.A.; investigation, M.T.E.-S., A.S.M., and A.M.S.; methodology, M.T.E.-S., A.S.M., and A.M.S.; resources, M.F.E. and B.M.A. writing-original draft, B.M.A., A.S.M., and A.E.T.; writing-review and editing, A.E.T., M.F.E., and B.M.A. All authors have read and agreed to the published version of the manuscript.

Funding: The authors extend their appreciation to the Deanship of Scientific Research at King Saud University for funding this work through research group no. (RG-1439-81).

Acknowledgments: The authors extend their appreciation to the Deanship of Scientific Research at King Saud University for funding this work through research group no. (RG-1439-81).

Conflicts of Interest: The authors declare no conflict of interest.

\section{References}

1. Erukainure, O.L.; Oke, O.V.; Daramola, A.O.; Adenekan, S.O.; Umanhonlen, E.E. Improvement of the Biochemical Properties of Watermelon Rinds Subjected to Saccharomyces cerevisiae Solid Media Fermen. PJN 2010, 9, 806-809.

2. Saguy, S.; Peleg, M. Accelerated and Parallel Storage in Shelf Life Studies in an Integrated Approach to New Food Product Development; CRC Press: Boca Raton, FL, USA, 2009; pp. 429-455.

3. Seabra, R.M.; Andrade, P.B.; Valentao, P.; Fernandes, E.; Carvalho, F.; Bastos, M.L. Anti-oxidant compounds extracted from several plant materials. Biomaterials from Aquatic and Terrestrial Organisms; Fingerman, M., Nagabhushanam, R., Eds.; Science Publishers: Enfield, NH, USA, 2006; pp. 115-174.

4. Anyasi, T.A.; Jideani, A.I.; Mchau, G.R. Effects of organic acid pretreatment on microstructure, functional and thermal properties of unripe banana flour. J. Food Meas. Charact. 2017, 11, 99-110. [CrossRef]

5. Anand, S.P.; Sati, N. Artificial preservatives and their harmful effects: Looking toward nature for safer alternatives. Int. J. Pharm. Sci. Res. 2013, 4, 2496.

6. Bondi, M.; Lauková, A.; de Niederhausern, S.; Messi, P.; Papadopoulou, C. Natural preservatives to improve food quality and safety. J. Food Qual. 2017, 4, 1-3. [CrossRef]

7. Speranza, B.; Corbo, M.R. Essential oils for preserving perishable foods: Possibilities and limitations. In Application of Alternative Food-Preservation Technologies to Enhance Food Safety \& Stability; Bevilacqua, A., Corbo, M.R., Sinigaglia, M., Eds.; Bentham Science: Sharjah, UAE, 2010; pp. 35-57.

8. Carocho, M.; Barreiro, M.F.; Morales, P.; Ferreira, I.C.F.R. Adding molecules to Food, pros and cons: A review of synthetic and natural food additives. Compr. Rev. Food Sci. 2014, 13, 377-399. [CrossRef]

9. Osman, A.O.; Mahgoub, S.; Sitohy, M. Preservative action of 11S (glycinin) and 7S ( $\beta$-conglycinin) soyglobulin on bovine raw milk stored either at 4 or $25^{\circ} \mathrm{C}$. J. Dairy Res. 2013, 80, 174-183. [CrossRef]

10. Vara, S.; Karnena, M.K.; Dwarapureddi, B.K. Natural Preservatives for Nonalcoholic Beverages. In Preservatives and Preservation Approaches in Beverages; Academic Press: Cambridge, MA, USA, 2019; pp. 179-201.

11. Dauda, A.O.; Abiodun, O.; Maiyaki, T.; Kayode, R.M.O. Microbiological evaluation of watermelon juice treated with serendipity berry (Dioscoreophyllum cumminsii) extract. Croatian J. Food Sci. Technol. 2017, 9, 19-24. [CrossRef] 
12. Mukherjee, P.K.; Nema, N.K.; Maity, N.; Sarkar, B.K. Phytochemical and therapeutic potential of cucumber. Fitoterapia. 2013, 84, 227-236. [CrossRef]

13. Warrier, P.K. Indian Medicinal Plants: A Compendium of 500 Species; Press Orientlongman: Chennai, India, 1994.

14. Alemu, T.; Girma, M. Indigenous knowledge on preservative plants and preservation techniques of milk and milk products in south wollo zone, northern Ethiopia. Int. J. Avian Wildl. Biol. 2018, 3, 127-131. [CrossRef]

15. Queirós, R.P.; Santos, M.D.; Fidalgo, L.G.; Mota, M.J.; Lopes, R.P.; Inácio, R.S.; Saraiva, J.A. Hyperbaric storage of melon juice at and above room temperature and comparison with storage at atmospheric pressure and refrigeration. Food Chem. 2014, 147, 209-214. [CrossRef]

16. Pinto, C.; Moreira, S.A.; Fidalgo, L.G.; Santos, M.D.; Delgadillo, I.; Saraiva, J.A. Shelf-life extension of watermelon juice preserved by hyperbaric storage at room temperature compared to refrigeration. LWT-Food Sci. Technol. 2016, 72, 78-80. [CrossRef]

17. Pinto, C.; Moreira, S.A.; Fidalgo, L.G.; Santos, M.D.; Vidal, M.; Delgadillo, I.; Saraiva, J.A. Impact of different hyperbaric storage conditions on microbial, physicochemical and enzymatic parameters of watermelon juice. Food Res. Int. 2017, 99, 123-132. [CrossRef] [PubMed]

18. Otero, L. Hyperbaric Storage at Room Temperature for Fruit Juice Preservation. Beverages. 2019, 5, 49. [CrossRef]

19. Lemos, Á.T.; Ribeiro, A.C.; Fidalgo, L.G.; Delgadillo, I.; Saraiva, J.A. Extension of raw watermelon juice shelf life up to 58 days by hyperbaric storage. Food Chem. 2017, 231, 61-69. [CrossRef] [PubMed]

20. Arabshahi-D, S.; Vishalakshi Devi, D.; Urooj, A. Evaluation of antioxidant activity of some plant extracts and their heat, $\mathrm{pH}$ and storage stability. Food Chem. 2007, 100, 1100-1105. [CrossRef]

21. Zhang, X.; Li, D.; Meng, Q.; He, C.; Ren, L. Effect of mulberry leaf extracts on color, lipid oxidation, antioxidant enzyme activities and oxidative breakdown products of raw ground beef during refrigerated storage. J. Food Quali. 2016, 39, 159-170. [CrossRef]

22. Thery, T.; Lynch, K.M.; Arendt, E.K. Natural Antifungal Peptides/Proteins as Model for Novel Food Preservatives. CRFSFS 2019, 18, 1327-1360. [CrossRef]

23. Meinert, L.; Broge, E.H.; Bejerholm, C.; Jensen, K. Application of hydrolyzed proteins of animal origin in processed meat. Food Sci. Nutr. 2015, 4, 290-297. [CrossRef]

24. Meshginfar, N.; Sadeghi, M.A.; Ghorbani, M.; Aalami, M. Effects of protein hydrolysate from sheep visceral on oxidative stability of soybean oil and chicken sausage. J. Food Process. Preserv. 2017, 41, e12875. [CrossRef]

25. Saad, A.M.; Osman, A.O.M.; Mohamed, A.S.; Ramadan, M.F. Enzymatic Hydrolysis of Phaseolus vulgaris Protein Isolate: Characterization of Hydrolysates and Effect on the Quality of Minced Beef during Cold Storage. Int. J. Pept. Res. Ther. 2020, 26, 567-577. [CrossRef]

26. Wan, W.; Xu, B. Development of an orange juice beverage formulated with oat beta-glucan and whey protein isolate. J. Sci. Food Agr. 2018, 98, 4685-4691. [CrossRef]

27. Smulders, F.J.M.; Greer, G.G. Integrating microbial decontamination with organic acids in HACCP programs for muscle foods: Prospects and controversies. Int. J. Food Sci. Technol. 1998, 44, 149-169.

28. Johnson, E.A.; Brekke, J. Functional properties of acylated pea protein isolates. J. Food Sci. 1983, 48, 722-725. [CrossRef]

29. Yoo, W.; Araki, T.; Saito, J.; Kurata, Y.; Tokita, K.; Kato, K.; Matsushita, M. Isolation and characterization of a novel chicken egg white protein with scavenger receptor cysteine-rich domains. J. Poult. Sci. 2013, 50, 159-163. [CrossRef]

30. Habib, M.R.; Iqbal, A. Processing of mixed vegetable juice from tomato, cucumber, and pumpkin. Food Sci. Technol. 2014, 2, 83-91.

31. Castro-López, C.; Sánchez-Alejo, E.J.; Saucedo-Pompa, S.; Rojas, R.; Aranda-Ruiz, J.; Martínez-Avila, G.C.G. Fluctuations in phenolic content, ascorbic acid, and total carotenoids and antioxidant activity of fruit beverages during storage. Heliyon 2016, 2, e00152. [CrossRef]

32. AOAC. Official Methods of Analysis of the Association of Official Analytical Chemist, 18th ed.; Gaithersburg, Md: Washington, DC, USA, 2005.

33. Ranganna, S. Handbook of Analysis of Quality Control for Fruit and Vegetable Products, 2nd ed.; MC GRAW HILL INDIA: New Delhi, India, 2004.

34. Chaplin, M.F.; Kennedy, J.F. Carbohydrate Analysis: A Practical Approach, 2nd ed.; IRL Press Ltd.: Cardiff, UK, 1994.

35. Škerget, M.; Kotnik, P.; Hadolin, M.; Hraš, A.R.; Simonič, M.; Knez, Ž. Phenols, proanthocyanidins, flavones, and flavonols in some plant materials and their antioxidant activities. Food Chem. 2005, 89, 191-198. [CrossRef] 
36. Ordonez, A.A.L.; Gomez, J.D.; Vattuone, M.A. Antioxidant activities of Sechium edule (Jacq.) Swartz extracts. Food Chem. 2006, 97, 452-458. [CrossRef]

37. Hanato, T.; Kagawa, H.; Yasuhara, T.; Okuda, T. Two new flavonoids and other constituents in licorice root: Their relative astringency and radical scavenging effects. Chem. Pharm. Bull. 1988, 36, 2090-2097.

38. Gulcin, I.; Kufrevioglu, O.I.; Oktay, M.; Buyukokuroglu, M.E. Antioxidant, antimicrobial, antiulcer and analgesic activities of nettle (Urtica dioica L.). J. Ethnopharmacol. 2004, 90, 205-215. [CrossRef]

39. Hunter, R.S. Scales for measurements of color differences. In Measurements for Appearances. J. Wiley Ed. 1975, 1, 133-140.

40. Larmond, E. Laboratory Methods for Sensory Evaluation of Food; Research Branch, Canada Department of Agriculture: Publication No. 1637. In Laboratory Methods for Sensory Evaluation of Food; Publication No. 1637; Research Branch, Canada Department of Agriculture: Winnipeg Kentville, NS, Canada, 1977; pp. $19-63$.

41. Bauer, A.W.; Kirby, W.M.M.; Sherris, J.C.; Turck, M. Antibiotic susceptibility testing by a standardized single disk method. Am. J. Clin. Pathol. 1966, 45, 493-496. [CrossRef] [PubMed]

42. Akl, B.A.; Maha, M.M.; El-Saadony, M.T. Biosynthesis of silver nanoparticles by Serratia marcescens ssp sakuensis and its antibacterial application against some pathogenic bacteria. J. Agric. Chem. Biotechnol. Mansoura Univ. 2020, 11, 1-8. [CrossRef]

43. Adegoke, G.O. Understanding Food Microbiology, 1st ed.; Shalom Prints: Ibadan, Nigeria, 2000; pp. 49-65.

44. Lee, P.S. Quantitation of microorganisms, chap. 2. In Practical Handbook of Microbiology, 2nd ed.; Goldman, E., Green, L.H., Eds.; CRC Press: Boca Raton, FL, USA, 2009.

45. Sheiha, A.M.; Abdelnour, S.A.; Abd El-Hack, M.E.; Khafaga, A.F.; Metwally, K.A.; Ajarem, J.S.; Maodaa, S.N.; Allam, A.A.; El-Saadony, M.T. Effects of dietary biological or chemical-synthesized nano-selenium supplementation on growing rabbits exposed to thermal stress. Animals 2020, 10, 430. [CrossRef]

46. Reda, F.M.; El-Saadony, M.T.; Elnesr, S.S.; Alagawany, M.; Tufarelli, V. Effect of dietary supplementation of biological curcumin nanoparticles on growth and carcass traits, antioxidant status, immunity and caecal microbiota of Japanese quails. Animals 2020, 10, 754. [CrossRef]

47. Elgorban, A.M.; El-Samawaty, A.M.; Yassin, M.A.; Sayed, S.R.; Adil, S.F.; Elhindi, K.M.; Marwa, B.; Khan, M. Antifungal silver nanoparticles: Synthesis, characterization and biological evaluation. Biotechnol. Biotechnol. Equip. 2016, 1, 56-62. [CrossRef]

48. El-Saadony, M.T.; El-Wafai, N.A.; El-Fattah, H.I.A.; Mahgoub, S.A. Biosynthesis, optimization and characterization of silver nanoparticles using a soil isolate of Bacillus pseudomycoides MT32 and their antifungal activity against some pathogenic fungi. Adv. Anim. Vet. Sci. 2019, 7, 238-249. [CrossRef]

49. Alizadeh, H.; Rahnema, M.; Nasiri Semnani, S.; Ajalli, M. Synergistic antifungal effects of quince leaf's extracts and silver nanoparticles on Aspergillus niger. J. Appl. Bio. Sci. 2014, 8, 10-13.

50. Kumar, V.; Kaur, J.; Gat, Y.; Chandel, A.; Suri, S.; Panghal, A. Optimization of the different variables for the development of a cucumber-based blended herbal beverage. Beverages 2017, 3, 50.

51. Sarmadi, B.H.; Ismail, A. Peptides are antioxidative from food proteins. Peptides 2010, 31, $1949-1956$. [CrossRef]

52. Afandi, R.; Walters, M.E.; Tsopmo, A. Antioxidant properties and potential mechanisms of hydrolyzed proteins and peptides from cereals. Heliyon 2019, 5, e01538.

53. Klimczak, I.; Małecka, M.; Szlachta, M.; Gliszczyńska-Świgło, A. Effect of storage on the content of polyphenols, vitamin $C$ and the antioxidant activity of orange juices. J. Food Compos. Anal. 2007, 20, 313-322. [CrossRef]

54. Rawel, H.M.; Czajka, D.; Rohn, S.; Kroll, J. Interactions of different phenolic acids and flavonoids with soy proteins. Int. J. Biol. Maccromol. 2002, 30, 137-150. [CrossRef]

55. Rawel, H.M.; Rohn, S. Nature of hydroxycinnamate-protein interactions. Phytochem. Rev. 2010, 9, 93-109. [CrossRef]

56. Jakobek, L. Interactions of polyphenols with carbohydrates, lipids, and proteins. Food Chem. 2015, 175, 556-567. [CrossRef]

57. Ozdal, T.; Capanoglu, E.; Altay, F. A review of protein-phenolic interactions and associated changes. Food Res. Int. 2013, 51, 954-970. [CrossRef]

58. Sęczyk, Ł.; Świeca, M.; Kapusta, I.; Gawlik-Dziki, U. Protein-Phenolic Interactions as a Factor Affecting the Physicochemical Properties of White Bean Proteins. Molecules 2019, 24, 408. [CrossRef] [PubMed] 
59. Vallverdú-Queralt, A.; Arranz, S.; Medina-Remón, A.; Casals-Ribes, I.; Lamuela-Raventós, R.M. Changes in phenolic content of tomato products during storage. J. Agric. Food Chem. 2011, 59, 9358-9365.

60. Kaur, G.; Aggarwal, P.; Javed, M. Effect of chemical additives on the shelf life of cucumber juice. Int. J. Eng. Res. Appl. 2014, 4, 206-209.

61. Sivakumar, G.M. Effect of tulsi leaf extract on Physico-chemical and microbial quality of raw milk. Int. J. Sci. Environ. Technol. 2017, 6, 1626-1631.

62. Kausar, H.; Saeed, S.; Ahmad, M.M.; Salam, A. Studies on the development and storage stability of cucumber-melon functional drink. J. Agric. Res. 2012, 50, 239-248.

63. Chandra, D.; Bharti, M.K.; Yadav, A. Development and quality analysis of watermelon juice blends with bitter gourd: Ginger juice during storage. IJCS 2017, 5, 1420-1424.

64. Kinh, S.A.E.H.; Dunne, C.P.; Hoover, D.G. Preparation and preservation of apple pulp with chemical preservatives and mild heat. J. Food Prot. 2001, 28, 111-114.

65. Aderinola, T.A.; Abaire, K.E. Quality Acceptability, Nutritional Composition and Antioxidant Properties of Carrot-Cucumber Juice. Beverages 2019, 5, 15. [CrossRef]

66. Francis, G.A.; Chinyelu, I.N.; Ebele, I.; Ahmed, O. Effect of preservatives on the physicochemical properties of watermelon and soursop fruit blend. Direct. Res. J. Agric. Food. Sci. 2017, 5, 333-337.

67. Hossain, M.N.; Fakruddin, M.D.; Islam, M.N. Effect of chemical additives on the shelf life of tomato juice. Am. J. Food Technol. 2011, 6, 914-923.

68. Breijyeh, Z.; Jubeh, B.; Karaman, R. The resistance of Gram-Negative Bacteria to Current Antibacterial Agents and Approaches to Resolve It. Molecules 2020, 25, 1340. [CrossRef]

69. Holetz, F.B.; Pessini, G.L.; Sanches, N.R.; Cortez, D.A.G.; Nakamura, C.V.; Dias Filho, B.P. Screening of some plants used in the Brazilian folk medicine for the treatment of infectious diseases. Mem. Inst. Oswaldo. Cruz. 2002, 97, 1027-1031. [CrossRef]

70. Cheruiyot, K.R.; Olila, D.; Kateregga, J. In-vitro antibacterial activity of selected medicinal plants from Longisa region of Bomet district, Kenya. Afr. Health Sci. 2009, 1, 42-46.

71. Gobbetti, M.; Minervini, F.; Rizzello, C.G. Angiotensin I-converting enzyme-inhibitory and antimicrobial bioactive peptides. Int. J. Dairy Technol. 2004, 57, 173-188. [CrossRef]

72. Jenssen, H.; Hamill, P.; Hancock, R.E. Peptide antimicrobial agents. Clin. Microbiol. Rev. 2006, 19, 491-511. [CrossRef] [PubMed]

73. Lei, J.; Sun, L.; Huang, S.; Zhu, C.; Li, P.; He, J.; He, Q. The antimicrobial peptides and their potential clinical applications. Am. J. Transl. Res. 2019, 11, 3919. [PubMed]

(C) 2020 by the authors. Licensee MDPI, Basel, Switzerland. This article is an open access article distributed under the terms and conditions of the Creative Commons Attribution (CC BY) license (http://creativecommons.org/licenses/by/4.0/). 